\title{
Kadın Giyim Modasında Siyah Renk Kullanımı*
}

\author{
The Use of Color Black in Women's Clothing Fashion \\ Sevda Demir Parlak, Tekstil ve Moda Tasarımı Bölümü, Dokuz Eylül Üniversitesi \\ Nesrin Önlü, Tekstil ve Moda Tasarımı Bölümü, Dokuz Eylül Üniversitesi
}

\begin{abstract}
Özet
Günümüz moda oluşumlarında hızlı değișimler yașanmaktadır. İnsanların dinamik yapılarından kaynaklanan sürekli değișim, tasarımcıları yeni arayışlara itmekte, dolayısıyla moda ve rengi oluşturan ögeler kendilerini yenilemek durumunda kalmaktadır. İnsan beğenisini şekillendiren en önemli ögelerden biri olan renk, tasarımcı ile kullanıcı arasındaki köprüyü doğrudan kurarak psikolojik algılamayı harekete geçirmektedir.
\end{abstract}

Sözsüz iletişim aracı olan giyimin, karşı tarafa iletmek istediği mesajı renk belirlemektedir. Renklerin anlamı tarihsel süreçte ve farklı kültürlerde yaşandığı dönemlere göre farklılık gösterirken, siyah renk kalıcı geniş bir anlam aralığına sahip olmuştur. Bu çalışma olumlu ve olumsuz, geniş anlam aralığına sahip olan siyah rengin günümüz kadın giyim modasının vazgeçilmez rengi olma nedenlerinin sorgulanması amacı ile hazırlanmıștır. Bu amaç doğrultusunda, siyah rengin tarihsel süreçte ve farklı kültürlerde yeri ve önemi incelenmiş, mitolojiler, efsaneler, destanlar ve geleneklerde yüklenen sembolik anlamları tespit edilmiştir. Dönem ve kültürlere göre siyah rengin din, siyasal, ekonomik, sanat, toplumsal kurallar ve değișimlerden nasıl etkilendiği ve anlam bakımından olumlu ve olumsuz kazanımları örneklerle ele alınmıştır.

Konu; siyah rengin kültürlere göre sembolik anlam ve psikolojik etkileri, toplumsal, sosyal, kültürel faktörler ve giyim kodları yönünden giyime yön veren bireysel ve toplumsal davranış biçimleriyle, giysinin işlevselliği ve simgesel kullanımı açısından incelenmiștir. Bu etkilerin kadın giyim modasında siyah renk kullanımına yansımaları tarihsel süreçte ele alınmıș, siyah rengin yoğun kullanıldığı dönemler belirlenmiştir. Belirlenen dönemler ve bu etkiler kapsamında, siyah renge yüklenen sembolik anlamlar tespit edilmiş ve moda eğilimleriyle bağlantıları kurulmuştur. Siyah rengi tasarımlarında kullanan modacılar belirlenerek, tasarım felsefeleri ve bu rengi kullanım nedenlerini ortaya koyan koleksiyon analizleri yapılmıştır.

Anahtar Sözcükler: Kadın modası, siyah renk, sembolik anlam.

Akademik disipin(ler)/alan(lar): Tekstil ve moda tasarımı.

\section{Abstract}

There are fast changes in today's fashion formations. The constant change due to the dynamic states of the people forces designer to seek new forms and thus the features that form fashion and color have to renew themselves. Color, one of the most significant features that affects human taste, triggers the physiological perception by forming a direct bridge between the designer and the wearer.

The message that clothing, which is a non-verbal communication form, aims to convey is determined by color. While the meanings of the colors vary according to historical periods and the eras of the cultures in which they exist, the color black has had a wide range of meanings.

This study was prepared with the aim of analysing the reasons why the color black became an indispensable in today's clothing fashion for women.

For this purpose, the place and importance of black in the historical process and in different cultures were analysed and the symbolic meanings attributed to it in mythologies, legends, epics and traditions were determined. According to the period and cultures, how the color black is affected by religious, artistic, political, financial and social rules and changes and positive and negative acquisition in terms of meaning were presented with examples.

The symbolic meanings and psychological effects of black were analysed in terms of social and cultural factors, dress codes, and individual and social behaviour patterns. Then the function and symbolic meaning of the clothing were examined. The reflections of these effects on the use of color black in women's clothing were examined throughout history in the light of the fashion trends of the day. The design philosophy of the fashion designers that employ black in their designs were also analysed and critically asssessed.

Keywords: Women's fashion, black color, symbolic meaning. Academical disciplines/fields: Textile and fashion design.

* Bu makale, Sevda Demir Parlak'ın 2020 yılında Dokuz Eylül Üniversitesi Güzel Sanatlar Enstitüsü, ‘Tekstil Ana Sanat Dalı’ sanatta yeterlik programında savunduğu 'Kadın Giyim Modasında Siyah Renk' ismini taşıyan sanatta yeterlik tezinden üretilmiștir.

- Sorumlu Yazar: Sevda Demir Parlak, Tekstil ve Moda Tasarımı Bölümü, Dokuz Eylül Üniversitesi

- $\quad$ Adres: Dokuz Eylül Üniversitesi Güzel Sanatlar Fakültesi, DEÜ Tınaztepe Yerleşkesi, Adatepe Mah. Doğuş Cad. No: 209, 35390 Buca/İzmir

- $\quad$ e-posta: sevda.demirparlak@deu.edu.tr

- ORCID0000-0002-9521-2959

- Çevrimiçi yayın tarihi: 25.09 .2021

- doi: $10.17484 /$ yedi. 907070 


\section{Giriș}

Moda tarihi içerisinde giysiler görünenden daha derin birer anlam tașıma aracı olarak kullanılan simgelerdir. Giysideki anlamlar malzeme, renk, kesim, yenilik açısından belirli tercihlerin algılanmasına dayalıdırlar. Renk algısı, coğrafya ve iklimle ilişkilendirilen toplumsal bir olgudur ve giyimde çeşitli mesajlar içermektedir. Pastoureau (2016, s. 27-29), rengi oluşturan, ona tanımını ve anlamını veren, kodlarını ve değerlerini meydana getiren, pratiklerini düzenleyen ve önemini belirleyenin toplum olduğunu belirtmiştir. Buna paralel olarak renklerin, zaman ve mekândan bağımsız olduğunu, bütün uygarlıklarda ortak, evrensel bir simgesellik taşımadığının altını çizerek tam tersine, renklerle ilgili sorun ve tartışmaların son derece kültürel olması nedeniyle tarihçinin dönem ve coğrafi alanlarla oynamasına imkân tanımadığını özellikle vurgulamaktadır.

Renklerin anlamı kültürlere göre değişiklik göstermesine karşın, siyah renk, diğer tüm renklerden daha geniş bir sembolizm ve anlam aralığına sahiptir. Bununla ilişkili olarak Anne Hollander, simgesel ve optik gücünün birleşimiyle ön plana çıkan siyah rengin, giyim modasını etkisi altına aldığını, tekrarlanan döngüler halinde popüler olduğunu ve anlam haznesine yüzyıllar boyunca yeni anlamlar yüklediğini vurgulamıştır (Harvey 2008, s. 80).

Tarihte siyah rengin kullanımıyla ilgili olarak Harvey (2008, s. 78), siyah rengin esas olarak erkek kıyafetlerine özgü bir durum olduğunu belirtmektedir. Zaman içerisinde keder, kayıp, tevazu, suçluluk ve utancı simgeleyen, ışığı ve rengi olmayan siyah renk, erkekler tarafından, eksikliğini hissettikleri ya da kaybettiklerinin değil, bilakis sahip oldukları gücün, mevkiinin, efendiliğin, hâkimiyetin bir simgesi olarak benimsenip kullanılmıştır. Kadın kıyafetlerinde ise neredeyse içinde bulunduğumuz yüzyıla değin, siyah sadece pişmanlık ve yas durumlarında kullanılabilecek bir renk olmuştur. Hatta geçmişte göz alıcl, zengin ve güçlü kadınların bile görkemli siyahlar giyebilmeleri için matemli olmaları veya tövbekâr olmaları gerekmiştir.

Bu çalışma; pek çok kültürde matemi, ciddiyeti, endişeyi, otoriteyi ve gücü simgeleyen siyah rengin özellikle Orta Çă̆ Avrupa'sında yalnızca erkekler ve soylular tarafından kullanılırken, günümüz kadın giyim modasının vazgeçilmez rengi haline gelme nedenlerinin sorgulanması amacı ile hazırlanmış kapsamlı bir araştırma niteliğindedir. Bu amaç doğrultusunda, tarihsel süreçte sadece siyah rengi kapsayacak, giysi sistemlerinin temelindeki toplumsal kodlar, gündelik yaşam ve maddi kültürü içeren ögeler ele alınarak, siyah rengin sembolik anlamları ve psikolojik etkileri araştırılmış, moda eğilimlerine yansımaları örnekler ile açıklanmıştır.

\section{Tarihsel Süreçte Siyah Rengin Sembolik Anlamları}

Ulaşılan kaynaklarda, ilkel toplumlardan itibaren birçok kültürde giyim modasını etkisi altına alan siyah renk, tüm mitolojiler, efsaneler, destanlar ve geleneklerde Dünya'nın ilk oluşumu ile ilișkilendirilmiștir. Evrenin öncesiz ve sonsuz olduğu, dolayısıyla tarihin bir başlangıcının olmadığını kabul eden çoğu mitoloji, Dünya'nın kuruluşunu anlatmak veya açıklamak için karanlıklardan oluşan ilk dünya imgesine başvurmuştur.

Rengin arketip kuvveti, sözlü ve sözsüz iletișim çağında; mitolojilerde, destanlarda, dini törenlerde, sanatın dili olan şiirlerde ve resimlerde kullanılan sembol ve metaforlarda görülmektedir. İlk mitlerin ve inançların incelenmesi sonucu,

İnsanların tanrılarını en baștan, dünyayı aydınlatan ve ilkel gecenin kaosu olan biçimsiz karanlığı iten ışık kaynağı ile bağladığını ortaya koymaktadır. Bu; Hint, Çin, Mezopotamya, Pers, Maya ve Aztek gibi eski kültürlerin yanı sıra Avrupa'daki Norsemen ve Druidler için de geçerlidir. Siyah ve beyaz (ya da sadece koyu ve açık), tüm ilkel dillerinde isimler verilen ilk renkler olmuşlardır. (Hope ve Walch, 1990, s. 280)

Mitolojilerde bereketin, verimliliğin, analığın ve doğurganlığın simgesi olan, farklı kültürlerde farklı isimlerle bilinen, örneğin; Anadoluda Kibele (Türk kültüründeki adıyla Sibel), Efes'te Artemis ve Diana, Hindular'da Krişna ve Kali, Eski Mısır'da İsis ve yine Eski Mısır ve Yunanlılarda Osiris, Yunan ve Roma'da Demeter, Afrodit, Ceres, Hekate gibi ana tanrıça protohistorik heykelcikleri simgesel olarak hep siyahtır ve tanrıçaların giysileri de bu renktedir. 
Siyah yalnızca Avrupa'da değil, Asya ve Afrika'daki başka mitolojilerde de genelde doğurganlığın, verimli toprağın ve yağmurla şişmiş kara bulutların, yani bereketin simgesel rengi olarak karşımıza çıkmaktadır. Örneğin Mısır'da, Nil sularının taşkınlığı sonucu bıraktığı balçık siyah renklidir ve bereketi simgelemektedir (Pastoureau, 2016, s. 24).

Geleneksel maneviyat anlayışı ve dinsel pratikler yönünden de renkler büyük bir önem taşımaktadır. Siyah, Müslümanlık ve Hristiyanlık'ta fanilik, son ve sonluluk gibi sembolik açılımları nedeniyle özellikle batı toplumlarında daima keder, ölüm ve matem rengi olarak benimsenmiștir (Varlı Gürer, 2015, s. 23).

Orta ve Yakın Doğu, Mısır ve hatta Eski Yunanlılarda siyah rengin sahip olduğu iyicil boyut olan verimlilik, doğurganlık, tanrısallık imparatorluk Roma'sında kaybolarak, acı ve matem rengi olmuştur. M.Ö. 2. yüzyıldan itibaren Yunan ve Romalı yetkililerin cenaze törenlerinde çok koyu renkli ya da siyah renk giysiler giymeye başlamaları Avrupa'daki yas kıyafetleri âdetinin başlangıcı olmuştur (Pastoureau, 2016, s. 40-41). Zamanla siyah giyme geleneği yaslı ailelere ve nihayetinde toplumsal ve coğrafi olarak Modern Çă̆’a dek giderek yaygınlaşıp bir alışkanlığın temelini oluşturarak dünyaya yayılmıștır.

Siyah renge, farklı kültürlerde, arketip sembolik anlamlarına bağlı sosyo-politik nedenlerden dolayı, özellikle konuşma dili ve dini kullanımlarda değişken ve karmașı yeni anlamlar eklenmiștir. Örneğin;

Amerika ve Kanada için siyah ölüm, kötülük, günah, hiçlik, iş, yetişkin, resmi, seksi; Latin Amerika ve Meksika için yas, din, saygl, ölüm; Brezilya için sofistike, yetki, yas, din, formalite; Batı Avrupa için yas, formalite, ölüm, kötülük, zarafet, sofistike; İngiltere, İskoçya, Galler ve İrlanda için yas, ölüm, onur; İspanya ve Portekiz için ölüm, güç, dindarlık; İtalya için alçakgönüllülük, ölüm, yas; Doğu Avrupa ve Yunanistan için kış; Singapur ve Malezya için yas; Kuzey Kore için karanlık, gizem, yas, su anlamlarını çağrıştırmaktadır. (De Bortoli ve Maroto, 2001, s. 1-27)

Renkler toplumsal kimlik ve statülerin belirlenmesi ve duyguların dile getirilmesi açısından kişinin giyim kuşam tercihiyle karşı tarafa vereceği mesajda tamamlayıcı ve güçlendirici bir unsur olarak kullanılmaktadır. Bireylerin renk tercihleri, içinde yașanılan toplumun demografik, sosyokültürel ve politik yapısı kadar, renklerin sembolik anlamları, psikolojik ve fizyolojik etkileri de önemli rol oynayarak moda ve mevsimsel değişimler paralelinde gerçekleşmektedir.

Siyah rengin sembolik anlamları genel olarak; ölüm, keder, kötülük, gizem, bilinmeyenle (kara delik) birlikte, faşizmin karası ve anarşinin kara bayrağı gibi toplam imha algısı uyandırma olarak, olumsuz anlam içerme şeklinde özetlenebilir. Siyah renk bütün bu olumsuz anlamlarına rağmen; ironik bir şekilde güç, otorite, istikrar, gizem, formalite, sofistike, zarafet, baştan çıkarıcı, prestijli bir renk olarak kabul edilmekte ve giyim tercihlerimize yansımaktadır. Diğer taraftan, fizyolojik ve psikolojik olarak siyahın otorite, güç, sofistike, onur ve ciddiyet çağrışımları bazı insanlar için güveni temsil ederken; bazıları için de korkutucu, kontrol edici, ulaşılmaz ve düşmanca bulunmaktadır. Siyah; gizem ve gizlilik havası yaratarak bazı insanlar tarafından baştan çıkarıcı ve seksi olmak amacıyla kullanılırken, bazı insanlar için ulaşılmaz kimliğinin arkasına saklanmalarını sağlamaktadır. Başarı odaklı ve hırslı insanlar ile nötr davranmak isteyen insanlar sıklıkla siyah renk tercih etmektedirler.

\section{Kadın Giyim Modasında Siyah Renk}

Giyim modasında renk kullanımı esasen renk sembolizme dayanmakta ve belirli sınıfların kültürel kuralları çerçevesinde, belirli renkleri kullanması kapsamı ile kişisel tercihleri doğrultusunda şekillenmektedir. "Giysiler; bir toplumun inançlarını, değerlerini, fikirlerini ve deneyimlerini oluşturan nesneler, uygulamalar ve kurumlar olarak nitelendirilerek kültürle özdeşleştirilir" (Barnard, 1996, s. 36). Toplumsal yapı ve kültürün yansıması olan modada genel olarak renk sembolleri geçici ve değişken olmasına karşın, siyah kalıcı ve renk sembolizmi açısında güçlü bir renk olarak moda tarihinde yerini almıştır.

Siyah renk simgesel ve optik gücünün etkisi ile giyim modasını etkisi altına almış ancak, esas olarak erkek giyimine özgü bir renk iken; kadın kıyafetlerinde, başlangıçta soylular dahil olmak üzere sadece yas ve pişmanlık için kullanıldığı görülmüşsür. Bu durumun en önemli nedeni; tarihte siyah kumaş boyası elde etmek uzun süren, pahalı ve zor bir iş olmasından dolayı, Antik Çağ'ın en eski dönemlerinden Orta Çağ'ın sonlarına kadar gerçek ve güzel bir tonda siyah boyanamamasıdır. Karşılaşılan zorluklar ve boyanın kumaşa eşit oranda dağılmaması nedeniyle siyah renk; tam bir siyah olmaktan ziyade çoğu zaman kahverengi, gri ya da laciverte yakın kirli ve donuk renkler ortaya çıkmıştır. Giysilerde bu görüntü tercih edilmediği için, 
çoğunlukla mütevazi ve toplumun alt sınıfını oluşturan kesim tarafından matem ve kefaret amaçlı özel durumlarda kullanılmıştır (Delmare ve Guineau, 2007, s. 42).

Avrupa kadın giyim modasında siyah rengin toplumsal önemi ve yaygın olduğu dönemler açısından modern popülaritesine bakıldığında, ulaşılan kaynaklarda resmi bir başlangıç tarihine rastlanmamaktadır. Ancak; "siyahın tarihsel olarak eski Yunanlılara dayanan bir keder belirtisi anlamı vardır. Aynı zamanda görünümünden dolayı da büyük ilgi görmüştür. John Harvey, Black The Story adlı kitabında, Romalıların yas için kıyafetlerini siyaha boyamalarına rağmen, şıklığı ödüllendirdiklerini belirtmektedir" (Brain, 2018, S. 9).

Romalılar hem matem kıyafetleri hem de şıklık için, siyaha çok yakın tonlardaki renkleri kullanmışlardır. Pastoureau're (2016, s. 153) göre; Avrupa genelinde, başlangıçta sadece varlıklı aileler ve aristokratların uyguladığı bir gelenek olan yas adetleri, seçkinleri taklit etmek isteyen halk arasında da yaygınlaşan bir moda ifadesi haline gelmiştir. Yas kıyafetleri, örneğin İngiltere'de Hristiyan kilisesi tarafından VI. yüzyılın başında tanıtılmış ve bu konuda kıyafet yönetmelikleri uygulanmıştır.

IX. yüzyıldan itibaren tevazu ve tövbenin sembolü olarak siyah manastır rengi olurken, X. yüzyıldan sonra siyah renk gündelik yaşamda ve toplumsal kodlarda daha ölçülü kullanımı ile simgesel olarak çifte anlamlılığının büyük bir kısmını yitirmiş, katı din kuralları ve kilisenin baskıcı yapısı çerçevesinde şekillenmiştir. XI. yüzyıldan itibaren ise tüm olumsuz anlamları ve pagan geleneklerinin etkisi ile Latin kilisesinin siyahın, Batı'da şeytani renk haline gelmesinde önemli rol oynadığı görülmektedir (Pastoureau, 2016, s. 61).

Toplumsal kural ve kodlar, Delmare ve Guineau'a (2007, s. 41) göre dinin baskıcı tutumu ile şekillenirken, giysilerde siyah renk kullanımında, dokuma sanayiinin gelişmesi ile artış gözlenmiştir. Siyasal, ekonomik ve toplumsal durumdaki değişiklikler ile siyah rengin simgeselliğinde de farklılaşma başlamış ve 1200’lerden itibaren dokumacılıkta güzel siyah kumaşlar üretilmiştir.

XI. yüzyıldan XII. yüzyıla geçiş dönemlerinde din adamları ve ilahiyatçılarının çoğuna göre siyah, renk konumunda değerlendirilmemiştir. Bu dönemlerden sonra siyah renge önce kraliyet mahkemeleri ve bazı hukukçular tarafından ilgi artmıș, toplumsal, kişisel ve maddi armalarda da kullanılmış; İngiltere, Fransa ve İtalya'daki birçok kentte özel statü elde etmiștir. Siyahın edindiği bu özel statü ile, edebiyatta kara şövalye sıklıkla konu olarak işlenmiş, çoktanrıcılığı ve ölüler âlemini çağrıştıran renk konumundan çıkarılmış ve kimliği gizlemenin rengi olarak kullanılmaya başlanmıştır. Siyah kıyafet çoğu zaman sosyal bir öneme sahip olmuş, XIII. yüzyılda kraliyet mensupları ve soylular tarafından da kullanılmıştır (Pastoureau, 2016, s. 7287).

XIV. yüzyılın ortalarına kadar Harvey'e (2012, s. 84) göre, kumaş ve giysilerde siyah tonları grimsi, mavimsi ya da kahverengimsi görünümlü ve mat, donukken; düz, dayanıklı ve güzel siyahlara ulaşmak pahalı ve sadece belirli bir sınıfın için mümkün olabilmiştir. Yaşam koşulları ile siyah giyme adetinin gelişimi açısından bu noktada önemli bir bağlantı örneğini şu şekilde verebiliriz: Solmuş ve iyi boyanamamış renkteki kıyafetler ya halk tarafından ya da XIV. yüzyıl Avrupası'nda etkili olan 'Kara Ölüm' veba salgını ve cüzamlılar tarafından giyildiğinden siyah rengin sembolik anlamlarından biri olan ölümle bağdaştırılmıștır (Harvey, 2013, s. 273).

Diğer taraftan, Pastoureau'e (2013, s. 81) göre; soyluların lüks ve ölçüsüz harcamalarının artması ile Avrupa'da Orta Çağ'ı etkileyen Protestan Reformu gerçekleşmiş ve tüm toplumsal sınıf ve kategorilerde giysi ve aksesuarlarla ilgili savurganlık karşıtı harcamaları sınırlandıran birtakım yasalar, kararnameler ve yönetmelikler uygulanmış ve koyu renkli, sade, iç karartıcı giysilere yönelim başlamıştır. Bu reform ile siyah; onurlu, ahlaklı ve erdemli bir renk olarak kabul edilmiş ve siyah renge olan talebi artırmıștır. Bu noktada; ideolojik hedefler, zengin müşteri ve toplumsal talepler ile tetiklenen kumaş boyamacılığının müşteri kitlesinin isteklerini gerçekleștirdiği ve siyah modasının başladığı değerlendirmesini yapabiliriz.

XIV. yüzyılın sonuna doğru İtalya'dan başlayarak Kuzey Avrupa'ya hızla yayılan siyah renk modası, IV. Philip'in babasının yası için bu rengi giymesi ile yaygınlığını artırmıştır. Siyahın, Avrupa'da yüzyıllardır güç rengi olduğu görülmektedir. Örneğin, 1600'lerde İspanyol asilleri, Katolik hiyerarşileri, Protestan aşırıcılar, akademisyenler, din adamları tarafından giyilmiştir. Siyahın yas, erdem ve statü ile ilişkisinden kaynaklanan kullanımına bakıldığında, toplumsal sınıf engellerini azalttığı hem burjuvalar ve yüksek sosyete hem de toplumsal sınıfın alt kesimini oluşturan uşak ve hizmetçilerin giyiminde etkin bir renk olduğu görülmektedir.

XV. yüzyılda orta sınıfın en çok tercih ettiği renk haline gelen siyah, günlük klyafetlerde ve iş elbiselerinde kullanılmıştır. Bunun en önemli nedeni Fischel, Baggaley, O’hara, Sturgeon ve Khurana'a göre $(2013$, s. 108) 
bu yüzyıla kadar yasta ya da soylu ve varlıklı sınıfa mensup olmayan kadınların siyah renk kullanamamasından kaynaklanmaktadır. XVI. yüzyılda Avrupa aristokratları için önemli bir renk olan siyah, ruhani değerler ile zenginliği de (bkz. Şekil 1) simgelemiştir.

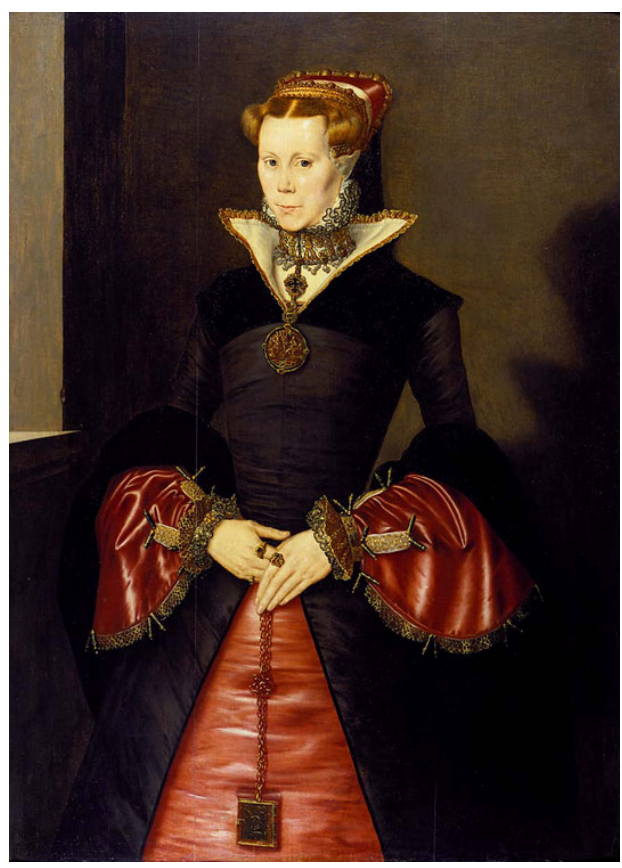

Şekil 1. I. Mary, Hans Eworth, 1553, Fitzwilliam Müzesi, Cambridge (De Young, 2019).

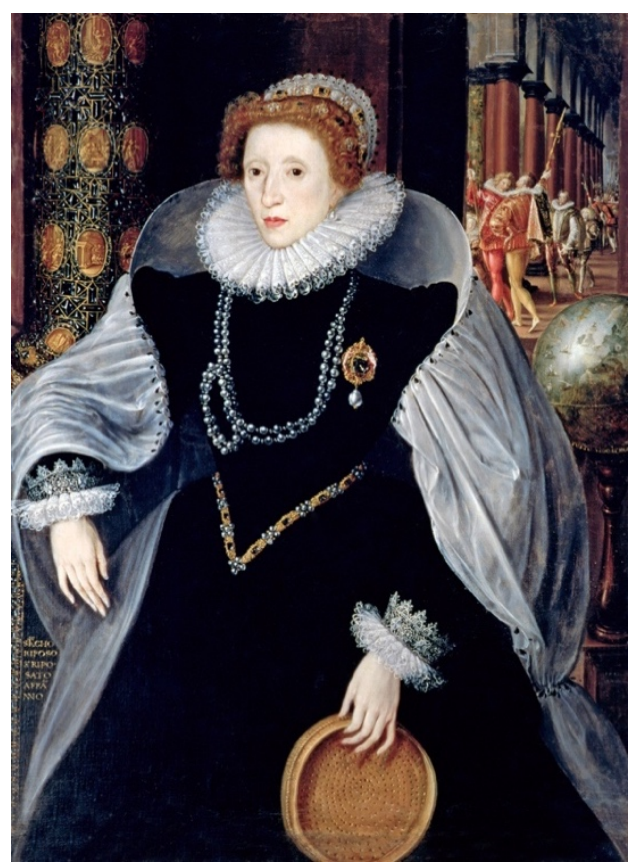

Şekil 2. Ingiltere kraliçesi I. Elizabeth, 1583 (Andrews, 2017).

İspanya, XVI. yüzyılda siyasi, kültürel ve ekonomik güç olarak Avrupa modasını belirleyen ülke konumuna gelmiştir. İmparator V. Charles (1500-1558) ve oğlu II. Philip (1527-1598) gibi İspanyol yöneticiler hemen hemen her gün siyah kıyafet giyerek siyahın yükselișine ve bu modanın yayılmasına katkıda bulunmuşlardır (Harvey, 2012, s. 77). Bu dönemde siyah rengin şık, asil, mesafeli ve vakur bir görünüm sağlaması nedeni ile Yeni İspanya, Hollanda, Napoli ve İngiltere (bkz. Șekil 2) gibi ağırlıklı olarak Protestan ülkelerde ve şehir devletlerinde yaygın olarak kullanıldığı yönünde bir değerlendirme yapılabilir.

Ancak, saraylının ve soyluların giyim kuşamda da uymak zorunda kaldıkları bazı kurallar vardır. XVI. yüzyılda “Zürih'te ve Cenevre'de, 17. yüzyıl ortalarında Londra'da ve bir sonraki yüzyılda da Pennsylvania'da, Protestan otoritelerinin büyük çoğunluğu tarafından kararlaştırılmış kıyafet normları ve savurganlığına karşı belirlenen kurallar son derece" (Harvey, 2012, s. 100) açıktır. Ayrıca

Japonya'da ipek giyimine kısitlamalar getiren Tokugawa döneminden (16001868) I. Elizabeth ve Özel Meclisi tarafından 1574'te yayınlanan ve düşes, markiz ve kontesler dışında kalan herkese, elbiselerinde samur kürkü dahil belirli malzemelerin kullanımını yasaklayan kıyafet yönetmeliğine kadar, hiyerarşik bir toplum yapısını yansıtan ve zaman içinde farklı kıtalar boyunca toplumsal statüleri belirleyen bağlayıcı giyim kuralları ile halkın çoğunluğuna birçok giyim stili ve kumaş çeşidini kullanmak yasaklanmıştır. (Fogg, 2014, s. 9)

Uygulamaya konulan bu kurallarla birlikte kıyafetlerde daha çok siyah renk olması için tarafsız ama çarpıcı bir ortam yaratmıştır.

Siyah renk, XVII. yüzyıldan itibaren İspanya, Fransa ve İtalya'ya özgü adetlerin Kuzey ülkelerine ve Batı Avrupa'nın tamamına yayılması ile kesin bir şekilde matem rengi olmuştur. Sadece aristokrasi değil artık ayrıcalıklı seçkin sınıf olan patrisyenler ile burjuvazi olarak adlandırılan sosyal statüsünü ve gücünü eğitiminden ve zenginliğinden alan kentli kişilerin oluşturduğu sosyal sınıfın bir bölümü de bu durumu benimsemiş ve giysi derlemeleri ile görgü kuralı kitaplarında yer alan daha kurallı bir uygulama ortaya çıkmıştır.

Matemle ilgili kıyafet parçaları, kumaşların ebadı, menkul ve gayrimenkuller üzerine konacak resim veya kumaşlar, matemin süresi, kimi zaman siyahı mora (yarı matem), sonra da açı griye (çeyrek matem) dönüştüren bir takvim 
belirlenmiştir. Bununla birlikte, matem renklerinin kurala bağlanması ve gerçek anlamda adetler arasında yer alması için 19. Yüzyılı beklemek gerekecektir. (Pastoureau, 2016, s. 154)

XVII. yüzyılın sonlarına doğru İspanya'nın güç kaybetmesi ile Fransa güçlenip ilerlemiş ve modanın değişimini belirleyen ülke konumuna gelmiştir. Bu dönemde sosyal ortamlarda daha renkli kıyafetler tercih edilirken, siyah modası azalmasına rağmen, siyah rengin asiller, orta sınıf ve ücretli çalışanlar için prestijini yine de korumaya devam ettiği görülmektedir.

Sanayi Devrimi ile başlayan ve Fransız Devrimi ile devam eden zaman sürecinde ise, geleneksel toplumdan modern topluma geçişte önemli değişimler yaşanmış, orta sınıf zenginleşmiş, lükse daha fazla ulaşılabilir olmuş, "gerçekleștirilen icatlar ile iplik ve kumaş üretimi daha ucuza mal" (Varlı Gürer, 2015, s. 71) edilmiştir. Bu gelişmeler; ekonomik, sosyal, politik ve kültürel alanları kapsayan yeni süreci de beraberinde getirmiş, modern çağın en önemli toplumsal hareketi Fransız İhtilali ile Fransa ve tüm Avrupa'da yoğun kargaşa ortamına neden olmuştur. Bu dönemde koyu renklere yönelim gerçekleşmiş ve siyah renk kullanımı da artmıştır. Anilin boyaların keşfi ile siyah renk, sınıf ve cinsiyet farkı olmaksızın sıkça kullanılmıştır.

Diğer taraftan Avrupa'nın varlıklı sınıfının geçmiş dönemlerde ortaya çıkan ve bu dönemde pekişen siyah giyme hevesi Harvey'e (2012, s. 185-186) göre, güç ve para ile ilgili olmanın yanı sıra feragat, yoksullaşma ve kayıpla da ilişkili olmuş ve Dickens, John Ruskin, Oscar Wilde, Baudelari, Gautier, Musset ve Maupassant gibi yazarlar eserlerinde keder, matem ve yas nedeni ile siyah giyme tutkusunu işlemişlerdir. Yüzyılın ilerleyen yıllarında çok dindar kesim ve yas tutma kıyafetleri dişında, siyah rengin kadın giyiminde kullanımı gerilemiştir. Yas tutma geleneği ve giyimi ile ilgili önemli etkiye sahip olan İngiltere Kraliçesi Victoria, 1861 yılında Prens Albert'in ölümünden kendi ölümüne (1901) kadar siyah giysiler giyerek (bkz. Şekil 3) siyah modasının şekillenmesi, yas kıyafetleri ve süresi ile ilgili yasa ve görgü kurallarının çıkarılmasında etken olmuştur. Matem dönemleri için özel olarak hazırlanmış siyah elbiseler, gerekli görüldüğünde ciddi ortamlarda da giyilebilmiştir.

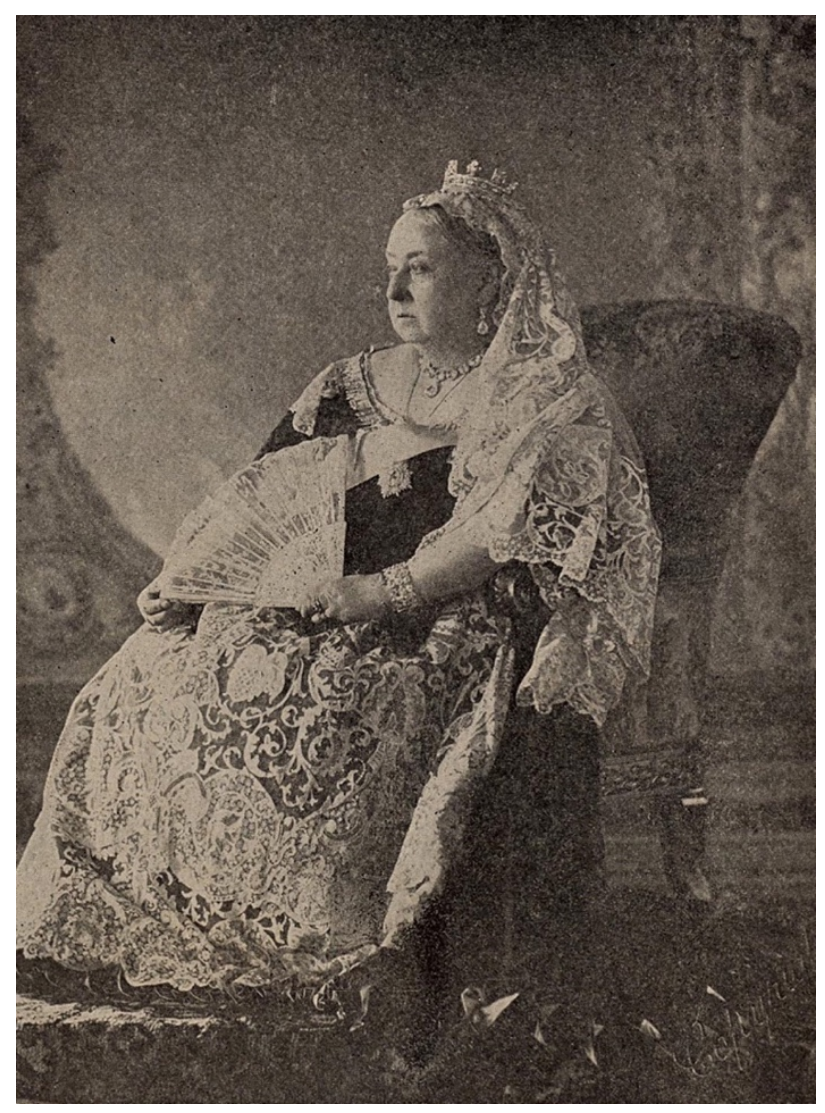

Şekil 3. Ingiltere kraliçesi Victoria, 1897 (Queen Victoria in 1897, t.y.) 
XIX. yüzyılın sonlarında geleneksel giysi biçimlerinin yerini mesleki giysiler ve yeni üniforma türleri almıştır. Giysilerin toplumsal denetim biçimi olarak kullanımının belirginleşmesi ve kişilerin toplumsal kimliklerinin belirli yönlerini gösteren kıyafetleri giyinmeye duydukları ihtiyaçtan kaynaklanan bu tip düzenlemelerde, siyah rengin ekonomik ve pratik oluşunun yansıra, resmiyetle ilişkilendirilen sembolik anlamı nedeni ile tercih edildiği tespitini yapabiliriz.

XX. yüzyıla gelindiğinde, toplumsal değişimler, kadın özgürlük hareketlerindeki artış, korselerin kaldırılması, Paris'in modanın merkezi olması, hazır giyimin 1900-1910 yılları arasında önemli bir endüstri haline gelmesi ve Birinci Dünya Savaşı ile modada hızlı değişimler gerçekleşmiştir. Siyah renk ciddiyet ve sadelikle ilişkilendirilerek, iş hayatında en çok kullanılan renkler arasında yerini almıştır. Yine siyah rengin yas ve ölümle ilgili kullanımının, bu yüzyılda yaşanan iki dünya savaşı ile ilgili olduğu görülmektedir.

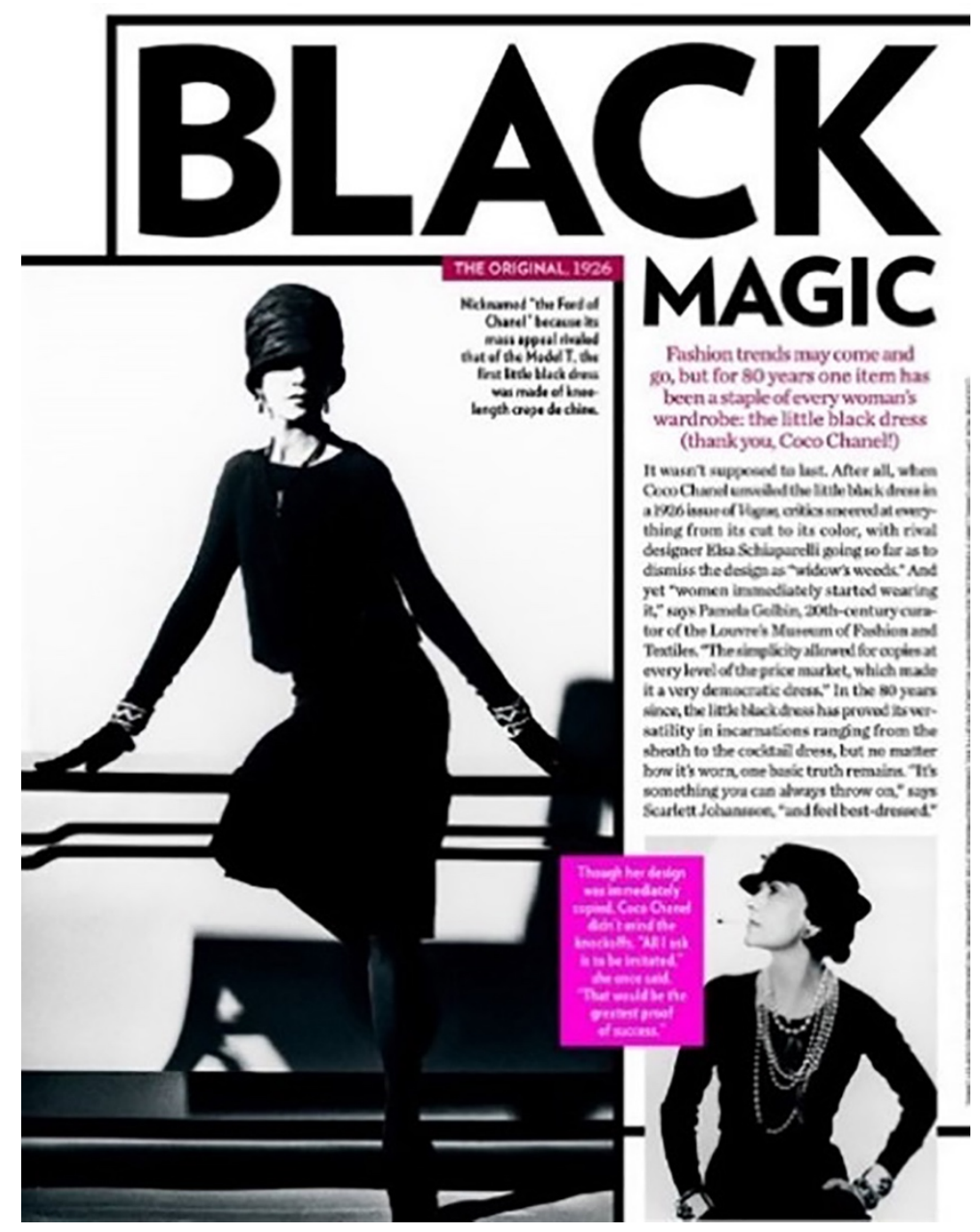

Şekil 4. The little black dress, Gabrielle Coco Chanel, 1926 (Exton, 2018)

Savaş sonrası dönemde siyahı modern renk haline getiren 1920'li ve 1930’lu yıllarda Coco Chanel, Madeleine Vionnet, Jeanne Lanvin, Jean Patou, Elsa Schiaparelli gibi modacılardır. Özellikle Coco Chanel'in The Little Black Dress adlı tasarımı moda tarihinde ikonlaşarak simgesel bir değer taşımıştır (bkz. Şekil 4). The Little Black Dress 1 Ekim 1926 tarihinde, Amerikan Vogue Dergisi tarafından moda dünyasına "İște Chanel imzalı bir Ford” manşetiyle sunulmuştur. Picardie’ye göre, (2019, s. 108) Vogue bu şık ve ağırbaşlı kıyafet serisinin kadınlar için vazgeçilmez bir üniforma olacağını ve Ford gibi bir otomobil kadar tüm dünyada tanınacağını öngörürken haklı çıkmıştır. Elbise mükemmel sadelik, işlevsellik ve modern görünüşü ile 1920'lerin ileri görüşlü kadınları için popüler hale gelmiştir. Bir kadın gardırobunun temel ögelerinden biri olan siyah elbise, moda devinimlerine göre değişim göstererek çekici, mütevazı, baştan çıkarıcı, pratik, şık, zarif, güçlü ya da modern bir çizgide kullanım kolaylığı sağlamış ve ofis, kokteyl, yemek veya cenaze törenlerinde giyilerek, yüzyıllardır modası geçmeyen gerçek bir klasik olmuştur. 


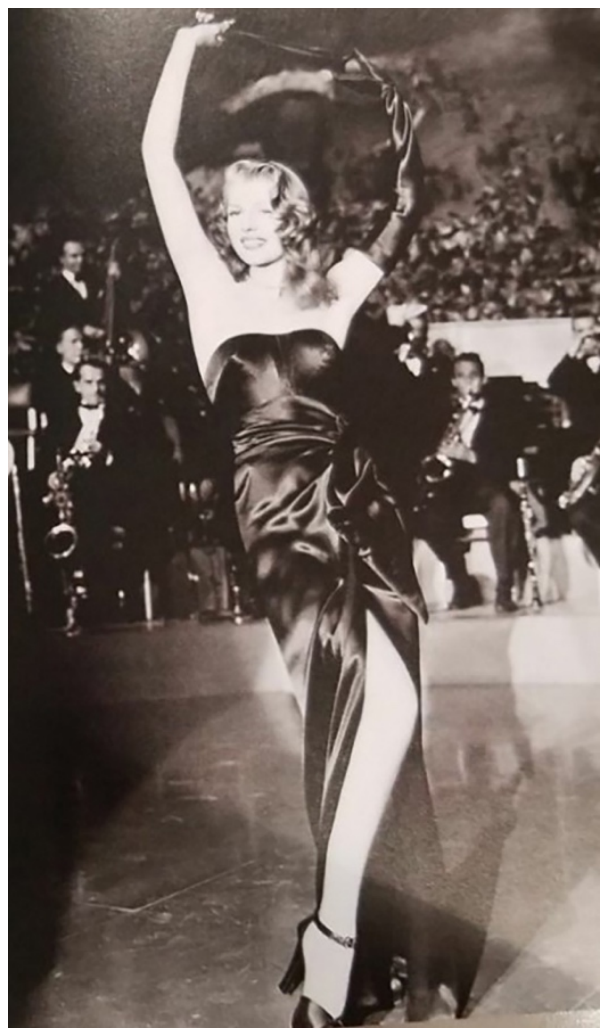

Sekil 5. Rita Haywort için Jean Louis tarafından 1946 yılında hazırlanan 'Gilda' film kostümü (Steele, 2007, s. 91)

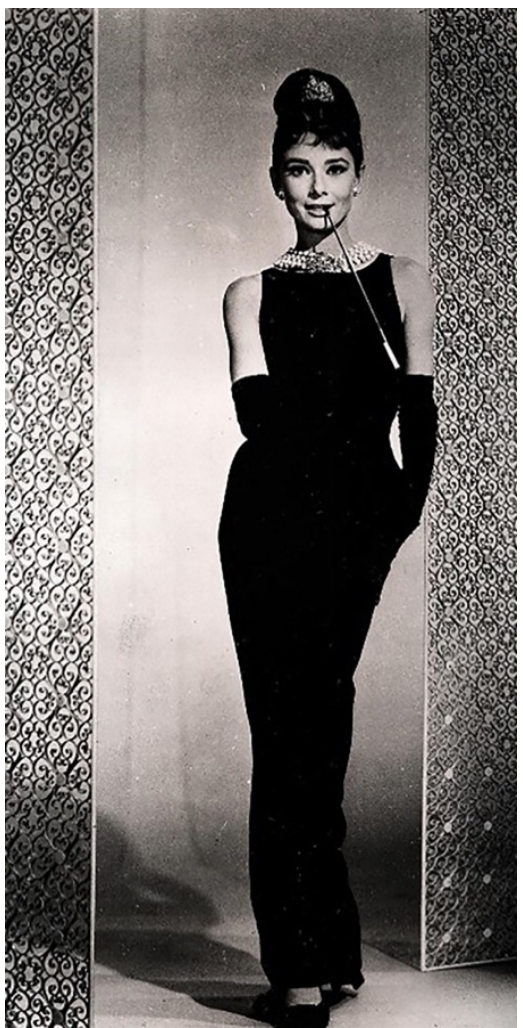

Şekil 6. Audrey Hepburn için Hubert de Givenchy tarafından hazırlanan 1961 yılında 'Breakfast at Tiffany's'film kostümü (Heyman, 2015)

Yine aynı dönemlerde, sinema dünyasının altın çağını yaşadığı ve film yıldızlarının giydiği göz kamaştırıcı siyah elbiselerin şıklığın göstergesi olarak yeni bir kadın imgesinin oluşmasında etkili olduğu görülmektedir (bkz. Şekil 5 ve Şekil 6).

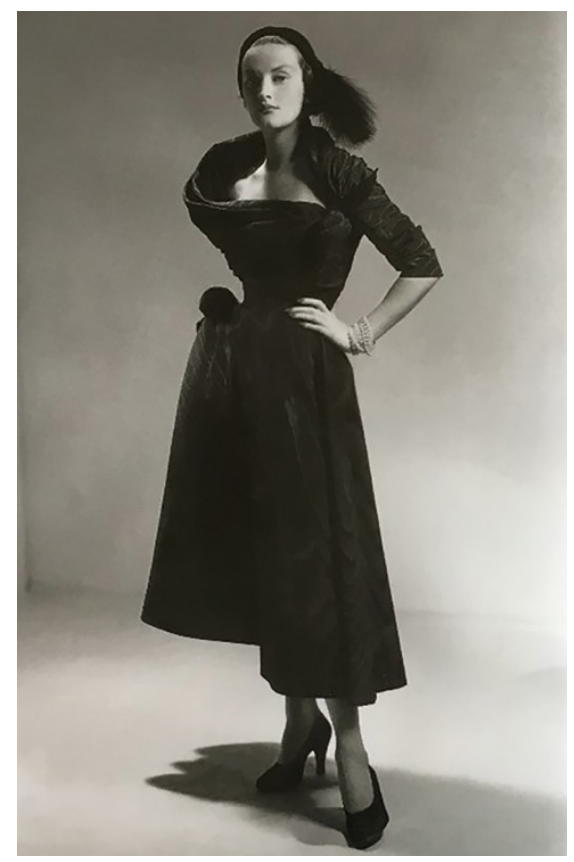

Şekil 7. Christian Dior, 1948 (Sinelair, 2014, s. 59)

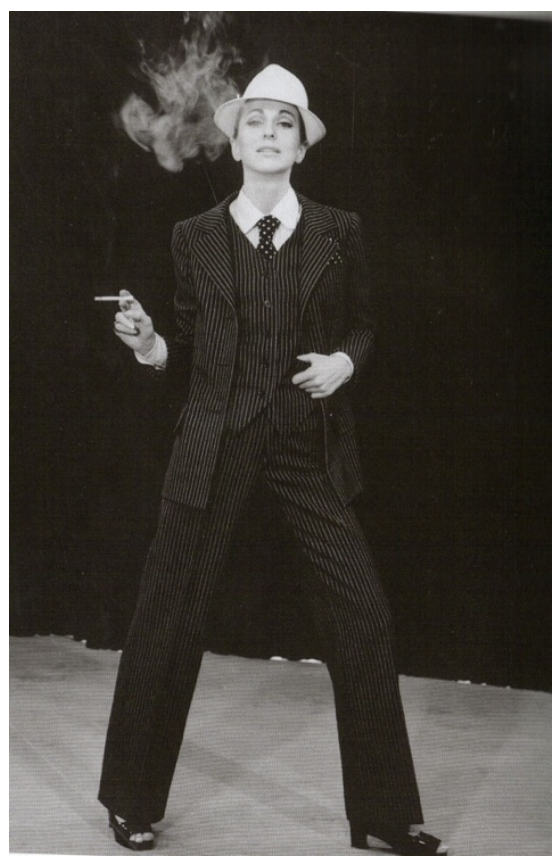

Şekil 8. Le Smoking, Yves Saint Laurent, 1966 (Fogg, 2014, s. 384) 
1930’lu yıllardan itibaren Cristóbal Balenciaga, Christian Dior, Hubert de Givenchy, Yves Saint Laurent, gibi modacılar siyah rengin popülerliğine katkıda bulunmuşlardır (bkz. Şekil 7 ve Şekil 8). 1950'li yıllarda siyah moda otoriteleri tarafından kabul görüp modanın temel renklerinden biri olurken, çeşitli alt kültürlerin ve entelektüel hareketlerin kıyafetlerinde de anlam taşıyıcı olarak yer almıştır. Örneğin, 1950'li yıllarda San Francisco ve New York çevresinde gelișen, toplumsal ve edebi bir hareket olarak nitelendirilebilecek Beatnik'lerin, Paris'te filizlenen varoluşçuluk (Miloşyan, 2014, s. 1) felsefesinin renginin de siyah olduğu görülmektedir. Benzer șekilde,1950'li yılların sonunda, Londra'da bir alt kültür olarak moda, müzik ve eğlence anlayışlarıyla ön plana çıkan Mod'larda siyah ve beyaz renkler ile kendilerini ifade etmişlerdir. Bu akım ile ekonomik özgürlügüne kavuşmuş, feminen, yenilikçi, cesur, bakımlı ve stil sahibi bir kadın imajı oluşmuştur. 1960’lı yıllar, günlük yaşam alanlarında siyah rengin kullanımının azaldığı gençlik kültürleri, siyasi ifadelerde kullanılmaya devam ettiği yıllar olmuştur.

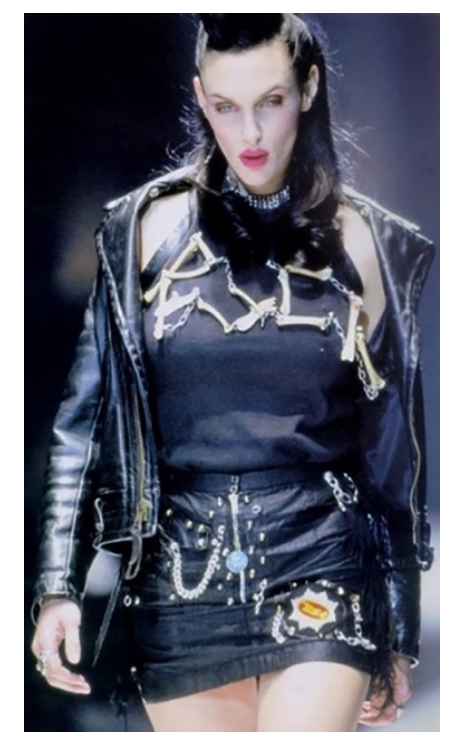

Şekil 9. , Saditionaries Koleksiyonu, Vivienne Westwood, 1977 (Buxbaum, 1999, s. 121).

Siyah rengin benzer kullanımı 1970’li yıllarda Punk akımı ile gündeme gelmiş, Malcolm McLaren ve Vivienne Westwood'un katkıları ile modaya yansımış ve gençler tarafından büyük ilgi görerek yaygınlaşmıştır (bkz. Șekil 9). Punk akımında da kullanılan siyah deri ceketler özellikle renginden dolayı, kullanım alanları ve kullanan kişilere göre anarşi, asilik, güç, disiplin ve resmiyetle ile ilişkilendirmiş, kadın giyim modasında sıklıkla kullanılan bir moda ürünü olmuştur. 1970'lerin sonları 1980'lerin başında ise, siyah renk Gotik modası ile anılır olmuştur. Gotik modası Punk sonrası Londra'da ortaya çıkarak, Orta Çağ'ın Neo-Viktorya döneminin karanlık, gizemli ve egzotik yönlerini yansıtan kadın giyim modasında siyah rengin sembolik anlamlarına güçlü vurgular yapan bir akım olarak karşımıza çıkmaktadır.

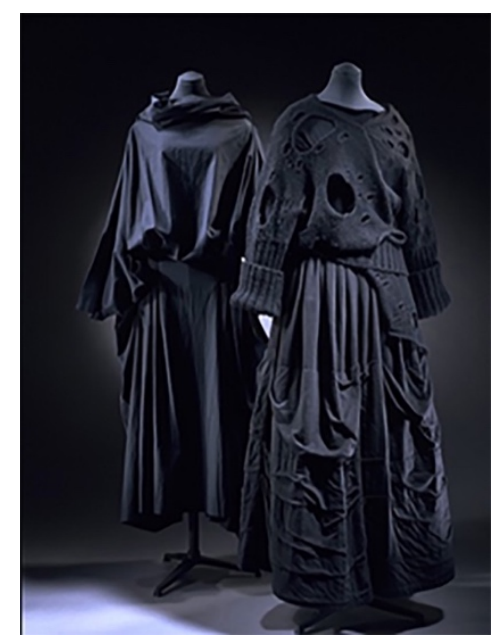

Şekil 10. Comme Des Garcons, Rei Kawakubo, 1982 (Master of deconstruction!, 2012). 
1980'li yıllarda Japon moda tasarımcıları Issey Mıyake, Rei Kawakubo (bkz. Şekil 10) ve Yohji Yamamoto, kendi Japon estetik duygularını ifade eden basit, sade, yırtık, estetik nitelikli bezeme içermeyen, varlık yerine yokluğu vurgulayan, ikinci el görünümlü, tek renkli giysilerinde daha çok siyah rengi kullanmışlar, cinsiyeti göz önünde bulundurmadan bedensiz olarak tanımlanan, aşırı büyük ürün tasarımları ile batı moda dünyasında şaşırtıcı birer çıkış yapmışlardır. Basında Post-Punk ve Grunge olarak tanıtılmış olsalar da Japon geleneksel giyim yapısından ilham alan, kendilerine özgü bir tasarım felsefesi sergilemișlerdir.

1980'li ve 1990'lı yıllarda siyah birçok tasarımcı için önemli bir renk olmuştur. Özellikle siyah rengi Domenico Dolce ve Stefano Gabbana, Gianni Versace, Azedine Alaia, Claude Montana, Thierry Mugler, Jean Paul Gaultier ve John Gallianao gibi tasarımcılar, kendi sitillerindeki tasarımlarında sıklıkla kullanmanın yanı sıra, siyah rengin fetişist alt etkenlerle de sıklıkla ilişkilendirilmesi nedeni ile kadının cinsel gücüne vurgu yapan tasarımlarda kullanarak fetiş, moda ve fanteziyi birleştirmişlerdir. "Bazı tasarımcılar siyahın zarafetine odaklanırken, diğerleri onun içindeki yıkımı ve cinsel sapkınlığı göstermektedir. Böylece siyah hem moda hem de moda karşıtlığı ile yakından ilişkilendirilen renk haline gelmiştir" (Steele, 2007 s. 24).

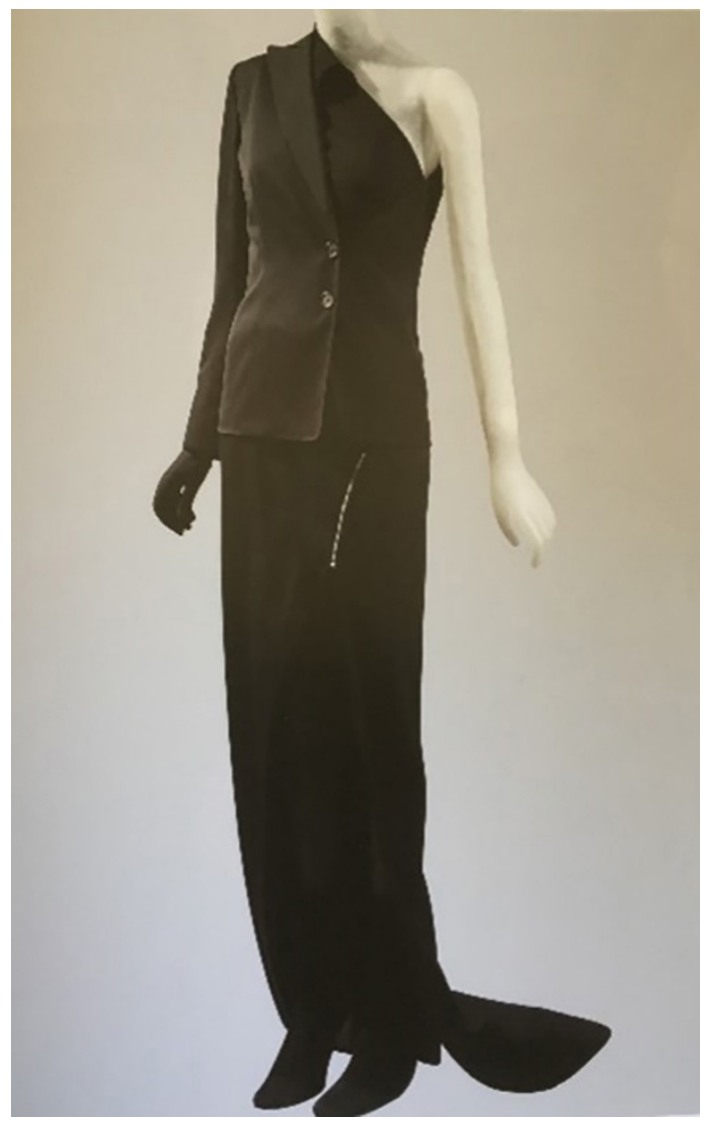

Şekil 11. Ann Demeuemeester, 1996 (Steele veMenkes, 2016, s. 180).

Japon moda tasarımcıları gibi, 1990'lı yıllarda Martin Margiela, Ann Demeulemeester (bkz. Şekil 11) ve Dries Van Noten gibi Belçikalı tasarımcılar da siyah rengi sıklıkla kullanmışlar ve moda dünyasına etkileyici yapıbozum/dekonsturiktivist tasarım örneklerini sunmuşlardır. Mackenzie’ye göre, (2017, s. 120) tasarımcılar yapıbozumu, çoğu kez giysi parçalarını ayırıp, dikişleri, eskitilmiş kenar baskılarını, içindeki yapısal ögeleri göz önüne serecek biçimde yeniden toplamak olarak nitelendirilerek, daha geniş bir bakışla; kıyafetlerin tasarımı, sunumu ve kullanılmasına ilişkin alışılagelmiş tutum ve yaklaşımlara meydan okuma olarak değerlendirmişlerdir. Belçikalı tasarımcıların çalışmalarında yapıbozumla birlikte, kıyafetin yapısı ile oynama, yer değiştirme imgesi ve sürrealist/gerçeküstücü yaklaşımlara da sıklıkla rastlanmakta ve diğer renklere oranla siyah renk daha çok kullanılmaktadır. 


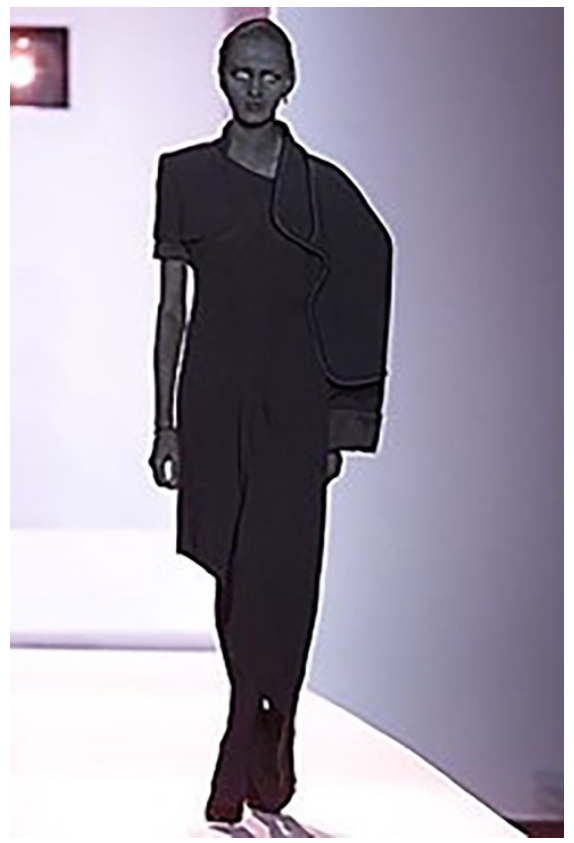

Şekil 12. Black Hole, Kış hazır giyim koleksiyonu, Victor \& Rolf, 2001 (Viktor \& Rolf fall 2001 ready to wear, 2001).

XX. yüzyılın sonlarında başlayan yapıbozum XXI. yüzyılda moda tasarımcılarını etkilemeyi sürdürmektedir. Fukai'e (2004, s. 32) göre Belçikalı tasarımcılar gibi Viktor\&Rolf'un kurucu ortakları Viktor Horsting ve Rolf Snoering de bu akımdan etkilenmişler ve 1998 yılında, Paris'te ilk koleksiyonlarında siyahın kült bir renk olarak tanıtılmasına katkı sağlamışlardır. Viktor\&Rolf'un kavramsal tarzda hazırladı̆̆ı, her biri tek bir renge dayanan ve üç ardişık konu içeren koleksiyon, siyah, beyaz ve mavi renklerinden oluşmaktadır. Viktor\&Rolf için renk, biçim ve sunum kadar değerli olmuştur. Şekil 12'de örneği yer alan, 2001 kış sezonu tamamen siyah renkten oluşan Black Hole hazır giyim koleksiyonunu sunan Victor\&Rolf'un tasarımlarında, kasıtlı hatalar ve çelişkili bilmeceler öne çıkmaktadır. Koleksiyonun konusu siyah olması nedeni ile, tasarımları sunan tüm mankenler makyajları ve yüzleri de dahil olmak üzere tepeden tırnağa siyah renge boyanmıştır.

Avrupa modasında etkili olan tasarımcılar gibi Türk tasarımcıları arasında siyah renk kullanımına öncülük eden Neslihan Yargıcı olmuştur. Tasarımcı, kendi imajında ve tasarımlarının neredeyse tamamında siyah rengi kullanması nedeni ile siyahların kadını olarak tanınmıștır. Vizon Show organizasyonu ile İstanbul'da yaptığı ilk defilesinin teması, kara çarşafın gece kıyafetine dönüşmesi olmuş ve podyumda Ramazan davulu eşliğinde sunumunu gerçekleştirmiştir. Birçok sinema filminin ve tiyatro oyununun kostümlerini tasarlayan Yargıcı, 1990’lı yıllarda popüler olan birçok pop müzik sanatçısının imaj danışmalı̆̆ını da yapmıştır. Yargıcı, Türkiye'yi New York, Tokyo, Johannesburg, Atina, Tel Aviv, Bakü, Dubai, Düsseldorf ve Osaka'da düzenlenen defilelerde, siyah renk ağırlıklı tasarımları ile temsil etmiştir. Ünal'a (2017) göre, Neslihan Yargıcı1980'li ve 1990'lı yıllarda hazırladığı ve yıllardır özel metotlarla sakladığı kıyafetleri bir araya getirerek, Women Black adlı koleksiyonunu 29 Eylül 2017 tarihinde, Banu Noyan koreografisi ile İzmir Mavi Bahçe'deki Vintage defilesinde sunmuştur. Avangard tarzda feminen ve maskülen çizgilere sahip tasarımlar yapan Yargıcı, siyah renk kullanımı ile gizeme, kendine güvene ve güce vurgu yapmıştır.

Yine Türk tasarımcı Arzu Kaprol'un tasarımcılığını yaptığı Que markası da koleksiyonlarında siyah rengi sıklıkla kullanmaktadır. Özellikle 2012 Sonbahar/Kış koleksiyonunu tamamen siyah renk tasarlayan Kaprol, Hürriyet gazetesine verdiği röportajda siyahın içindeki boyutu sevdiğini söylemekte ve siyah rengin bedeni veya sanılanın aksine vücuttaki deformasyonları değil, ruhu örttüğünü düșünmektedir. İfadesine siyahın bir tasarımcı için çalışması en zor renklerden biri olduğunu ve siyah kullanıldığında, tasarım farkını malzeme ve kupla verilmesi gerekliğinin altını çizerek, tasarımlarda daha özel teknikler kullanılması gerektiğini de eklemektedir (Aras, 2013). Arzu Kaprol'un Mart 2011 yılında Paris Moda Haftası kapsamında gerçekleșen 2011-12 Sonbahar/Kıș sezonu Archeology of Future adlı koleksiyonu da sadece siyah renk kullanılarak oluşturulmuştur. Kaprol koleksiyonda siyah renk kullanım sebebini; "Siyah renk içinde tüm renkleri barındırmakla birlikte her rengin içinde olmayanı yansıtmaktadır. Siyah aslında içinde siyah olmayan tek renk olması nedeni ile de her şeyi kapmaktadır." şeklinde açıklamaktadır (A. Kaprol, kişisel görüşme, 28 Nisan 2020). 


\section{Sonuç}

Tarihsel ve toplumsal bağlamda, kültür içeriklerine göre önemli bir konuma sahip olan siyah renk, günümüze değin moda tarihi içerisinde giysilere yüklediği sembolik anlamlarla dikkat çeken renklerden biri olarak değerlendirilmektedir. Giyim modasında diğer renklerde olduğu gibi siyah rengin kullanımının da renk sembolizmi sistemine dayandığı ve kültürel kurallar çerçevesinde şekillendiği, ancak, siyahın diğer renklerden daha geniş bir sembolizme ve anlam aralığına sahip olduğu görülmektedir. Bu bağlamda tarihsel süreçte, siyah renge farklı kültürler tarafından bulunduğu dönemin koşulları doğrultusunda; özellikle dini ve ahlaki yaklaşımlar, toplumsal kurallar, gündelik yaşam alanlarına göre şekillenen giyim sistemleri ve maddi kültür gibi unsurlara bağlı olarak, yüklenen olumsuz çağrışımlar zaman içerisinde, toplumsal ve kültürel değişimler paralelinde pozitif çağrışımlar ile değiştirilip, dönüștürülmüş ve siyah renk sembollerine oldukça değişken ve karmaşık yeni anlamlar eklenmiştir.

Sonuç olarak; geçtiğimiz birkaç yüzyıl boyunca, farklı nedenlerden ötürü ve farklı toplumsal sınıflara mensup kadınlar için siyah rengin, ölümün ve kaybın taşıyıcısı olmanın yanı sıra; zenginlik, saygınlık, dindarlık ve hatta isyanın sembolü olarak çok çeşitli çağrışımlara sahip olduğu görülmektedir. Siyah zaman içerisinde; keder sembolü olmaktan öte, yüksek moda sembolü, modern ve fetiş bir renk olarak kullanılırken, günümüzde pratik bir çözüm olarak günlük kullanım için de sık sık tercih edilen renkler arasında yerini almıștır. Psikolojik ve algı yönündeki araștırmalar referans alındığında, siyah renk giyimde soğuk ve güçlü bir etki yaratırken, duygusal saklanma ve korunma yönündeki etkisinin de olduğu görülmektedir. Siyah rengin kadın giyim modasındaki kullanım kökenlerinin ve sembolik anlamlarının okunması için hazırlanan bu çalışmada, siyah rengin kadın giysi siluetlerine; yas, resmiyet, güç, prestij, sofistike, zarafet, asil, asi, gizem, seksi gibi sembolik anlamlarına bağlı kullanımları ile yansıdı̆̆ı görülmektedir. Kadın giyiminde siyah rengin bu tip sembolik anlam kaynaklı kullanımlarında, kimlik ve statü belirleyici, duyguları ve verilmek istenen mesajı iletici, başkaları ile aynılaşma ya da ayrışma gibi soyut işlevler yüklenerek sözsüz iletişim aracı olduğu tespit edilmiştir. Siyah; görsel, duyusal, bilişsel, estetik etkisi güçlü bir renk olmakla birlikte, içerdiği olumlu ve olumsuz çağrışımları itibariyle de zıtlıkların ve sembolizmin en güçlü renklerinden biri olmuş, simgelediği anlam ve kavramlar aracılığıyla çok yönlü, zamansız ve modern gibi önemli işlevlere sahip olduğu sonucuna varılmıştır.

\section{Kaynakça}

Andrews, J. (2017). İște Rembrandt, (C. Ömürsuyu Seyis, Çev.). Bilnet Matbaacılık ve Ambalaj San. A.Ș.

Aras, Y. (2013, 26 Ağustos). Siyah bir yaşam bir stili, Hürriyet Gazetesi, https://vogue.com.tr/metropol/siyah-bir-yasam-stili

Barnard, M. (1996). Fashion as communication, Routledge.

Brain, M. (2018, 4 Şubat). Only black is the new black: A cultural history of fashion's favorite shade, Quartzy, https://qz.com/quartzy/1194798/only-black-is-the-new-black-a-cultural-history-offashions-favorite-shade

Buxbaum, G. (1999). Icons of fashion The 20th century, Prestel.

De Bortoli, M. ve Maroto, J. (2001). Colours across cultures: Translating colours in interactive marketing communications, European Languages and the Implementation of Communication and Information Technologies (Elicit) Conference'd sunulan bildiri. University of Paisley, 1-27, http://www.globalpropaganda.fresa.net/articles/TranslatingColours.pdf

De Young, J. (2019, 7 Temmuz). 1550-1559, 16th century, decade overview, Fashion History Timeline, https://fashionhistory.fitnyc.edu/1550-1559

Delmare, F. ve Guineau, B. (2007). Renkler ve malzemeleri, (O. Türkay, Çev.). Yapı Kredi Yayınları.

Demir Parlak, S. (2020) Kadın giyim modasında siyah renk (Tez No. 637075) [Yayınlanmamış sanatta yeterlik tezi, Dokuz Eylül Üniversitesi. Ulusal Tez Merkezi].

Exton, C. (2018, 26 Temmuz). History of the little black dress (and our favorite ones), Norestforbridget, https://www.norestforbridget.com/blogs/news/history-of-the-little-black-dress-and-ourfavorite-ones 
Fischel, A., Baggaley A., O’hara, S., Sturgeon A., Gersh C., ve Khurana, A. (2013) Moda geçmişten günümüze giyim kuşam ve stil rehberi, (D. Özen, Çev.) Kaknüs Yayınları.

Fogg, M. (2014). Modanın tüm öyküsü, (E. Gözgü, Çev.). Hayalperest Yayınevi.

Fukai, A. (2004). Fashion in colors, Assouline Publishing.

Harvey, J. (2008). Giysiler, renk ve anlam, (U. Apak, Çev.). Sanat Dünyamız, 107, YKY, 76-85.

Harvey, J. (2012). Siyah giyen adamlar, (E. Yücesoy, Çev.). Yapı Kredi Yayınları.

Harvey, J. (2013). The story of black, Reaktion Books.

Heyman, J. (2015, 4 Mayıs). Happy birthday, audrey hepburn! 10 things you never knew about_breakfast at tiffany'_s, Vogue, https://www.vogue.com/article/audrey-hepburn-birthday-breakfast-attiffanys

Hope, A. ve Walch, M. (1990) The color compendium, Van Ncstrand Reinhold International Company Limited.

Mackenzie, M.(2017). ...İzmler modayı anlamak, (M. Tuna, Çev.). Hayalperest Kitap 66, Moda 4.

Master of deconstruction!, (2012, 19 Şubat). Starsweare, https://franceslakin01.wordpress.com/2013/12/14/httpstarsweare-com20120219masters-ofdeconstruction-research-webpage/

Miloşyan, S. (2014, 21 Nisan). Siyahın felsefesi, Elle Dergisi, https://www.elle.com.tr/moda/modahaberleri/siyahin-felsefesi?sayfa=2

Pastoureau, M. (2013). Mavi bir rengin tarihi, (İ. Malak Uysal, Çev.). Can Sanat Yayınları.

Pastoureau, M. (2016). Siyah bir rengin tarihi, (M. Tufan, Çev). Sel Yayıncılık.

Picardie, J. (2019). Chanel efsanesi ve hayatı, (S. E. Ümitvar ve Z. Yeşiltuna, Çev.). Artemis Yayınları.

Sinelair, C. (2014). Vogue on Christian Dior, Abrams İmage.

Steele, V. ve Menkes, S. (2016). Fashion designers A-Z, Taschen.

Steele, V. (2007). The black dress, Harper Collins Publishers.

Queen Victoria in 1897, (t.y.). Queen Victoria, Salt Araştırma, Harika-Kemal Söylemezoğlu arşivi, https://archives.saltresearch.org/handle/123456789/26106

Ünal, S. (2017, 30 Eylül). Neslihan Yargıcı'dan 22 yıl sonra muhteşem defile, Milliyet Gazetesi, http://blog.milliyet.com.tr/neslihan-yargici-dan-22-yil-sonra-mutesem-defile/Blog/?BlogNo=570550

Varlı Gürer, Z. (2015). Giyimin dili: Siyasal iletişimde giyim kodlarının rolü, Volga Yayıncılık.

Victor\&Rolf fall 2001 ready to wear. (2001, 9 Mart). Vogue Runway, https://www.vogue.com/fashionshows/fall-2001-ready-to-wear/viktor-rolf/slideshow/collection\#34 